\title{
CONTROL OF INSECT PESTS ATTACKING TOMATO CROPS IN DISTRICT BAJAUR KHYBER PAKHTUNKHWA
}

Muhammad Yahya ${ }^{1}$, Muhammad Ajmal Khan ${ }^{2}$, Fazle Subhan ${ }^{3}$, Ali Hazrat ${ }^{1 *}$, Javed Khan ${ }^{5}$, Aftab Amin ${ }^{4}$, Hayat Ullah ${ }^{1}$ and Tabinda Nowsheen ${ }^{1}$

\begin{abstract}
Tomato plant (Lycopersicon esculentum) is a widely cultivated vegetable crop. The plant is economically very important. To ensure a successful and economically viable harvest, it is essential that all aspects of its production to be monitored. At present, there is a limited scientific data regarding the use of pesticides in relation to the seasonal incidence of insect pests in the Bajaur district of Pakistan. This study was carried out at a local farm, where the efficacies of Flurofenafire pesticide were examined. The pesticide Flurofenafire was applied once a week to examine its efficacy. The stability of the pesticide was highly dependent on the weather. The occurrence of rain within 24 hours of spraying resulted in Aphid, Jassid, White fly, Thrips and Fruit borer infestations. Aphid infestations were observed on the tomato crop in May 2019, which peaked in July. Bemisia Tabaci infestations peaked in August. Amrasca Biguttula populations peaked in September 2019. Scirtothrips dorsalis and Helicoverpa armigera infestations were also observed on the tomato crops and caused significant damage. The application of Flurofenafire was able to control these infestations. In conclusion the pesticide Flurofenafire was found effective against a wide range of insect pest of tomato plant.

\section{Keywords: Flurofenafire, Pest, Pesticide, Seasonal incidence, Lycopersicon esculentum}

Citation: Yahya , M.; M.A. Khan; F.Subhan; A. Hazrat; J. Khan; A. Amin; H. Ullah; T. Nowsheen. 2021 Control of insect Pests attacking tomato crops in District Bajaur, Khyber Pakhtunkhwa. Pak. J. Weed Sci. Res., 27 (3):381-395.

1Department of Botany, University of Malakand, Chakdara Dir Lowe, KP Pakistan. 2Centre of Biotechnology and Microbiology, University of Peshawar, KP, Pakistan. 3Department of Zoology, University of Karachi Pakistan. 4School of Chinese Medicine and Department of Biology, Hong Kong Baptist University, Hong Kong.

5Department of Botany, Hazara University of Mansehera.

Corresponding Author: E-mail: aliuom@gmail.com 


\section{INTRODUCTION}

The tomato plant (Lycopersicon esculentum) is grown in tropical areas as a perennial plant, while elsewhere it is grown annually. It is the second most cultivated plant all around the world (Akhtar et al. 2010). In 2018 world processing tomato council (WPTC) reported 37.1 million metric tons production of tomato worldwide (WPTC, 2018). The plant contains vitamins $\mathrm{A}, \mathrm{B}$ and $\mathrm{C}$, and is composed of $94 \mathrm{~g}$ of water, $0.5 \mathrm{~g}$ minerals, $0.8 \mathrm{~g}$ fiber, $0.9 \mathrm{~g}$ protein, $0.2 \mathrm{~g}$ fat and $3.6 \mathrm{~g}$ carbohydrate and other elements like $48 \mathrm{mg}$ calcium, 0.4 $\mathrm{mg}$ iron, $356 \mathrm{mg}$ carotene, $0.12 \mathrm{mg}$ vitamin $\mathrm{B}-1,0.06 \mathrm{mg}$ vitamin $\mathrm{B}-2$ and $27 \mathrm{mg}$ vitamin $C$ in each $100 \mathrm{~g}$ edible ripen tomato (Afreen et al., 2017). Various factors are associated with tomato production reduction such as pests (Luckmann and Metcalf, 1975). The fruit borer Heliothis armigera (Hub) is one of the major pests that can damage the plant and accounts for 85-93.7 \% of crop failure (Afreen et al., 2017). Whitefly infestations also damage the tomato plant by feeding and transmitting plant viruses that cause tomato leaf yellowing and leaf curling. Furthermore, white files are known carriers of tomato yellow leaf curl virus (TYLCV) and selectively colonize healthy plants (Kil et al., 2016). Some phytopathogen infections can change the preference of vector carrying insects as well (Ueda. et al., 2018). Adult Thrips are known to transmit tospo viruses. Both larval and adult Thrips can infect the host plant. The early larval instars can acquire the virus and later instar larvae and adults can transmit the virus (Riley et al., 2011). Fruit borers, Helicoverpa armigera (Hubner) belong to the Noctuidae family. They are polyphagous and are known to feed on over a hundred plant species including broadly developed and financially critical crops, such as cotton, maize, tobacco, pigeon pea chickpea and tomato.

Fruit loss of $53 \%$ was reported in Peshawar, KP Pakistan in 2007 (Inayatullah et al., 2007). The yield of tomato can be increased by various ecofriendly weed managementstechniques (Ijaz et al., 2017, Khalid et al., 2005). Farmers in the study area mostly used traditional methods for pest control, which are both safe and environmentally friendly (said et al., 2015). It utilizes biological pest control methods that allow for the deliberate manipulation of the environment making it less favorable for the pests to reproduce (said et al., 2015). Natural food sources for the pests are eliminated, while making the environment more favorable for their natural predators. The process involves sanitation, destruction of debris, alternate hosts, and volunteer plants. Moreover, modifications to the planting and harvesting periods are effective methods which protect the tomato crop from pest infestation. Crop rotation techniques, tillage practices, habitat diversification, cropping system, intercropping and plant density manipulation techniques are also utilized. In this study, the seasonal incidence of insect pests that affect tomato plant cultivation in Bajaur district of Khyber Pakhtunkhwa province, Pakistan, was evaluated and recommendations for improving the existing practices were examined.

\section{MATERIALS AND METHODS}

\section{Study Area}

The experiment was carried out at Bajaur district of Khyber Pakhtunkhwa, Pakistan (Figure 1). Bajaur District is located in between $34^{\circ}-41^{\circ} \mathrm{N}$ and $71^{\circ}-30^{\circ} \mathrm{E}$ with total area of $1290 \mathrm{~km}$ and population of approximately 1.124 million. Bajaur District is surrounded on the northeast by Dir. District, northwest Afghanistan, southwest District Mohmand, and southeast Malakand Division. The climate is semiarid to arid having four seasons Spring Autumn extreme winter and summer seasons. The winter season is from November to March; at times temperature plunges below freezing point. Average maximum and minimum temperatures in these months are $5-16{ }^{\circ} \mathrm{C}$. The summer season is from May to October; average maximum and minimum temperature in this period is in the range of $23-43^{\circ} \mathrm{C}$. 


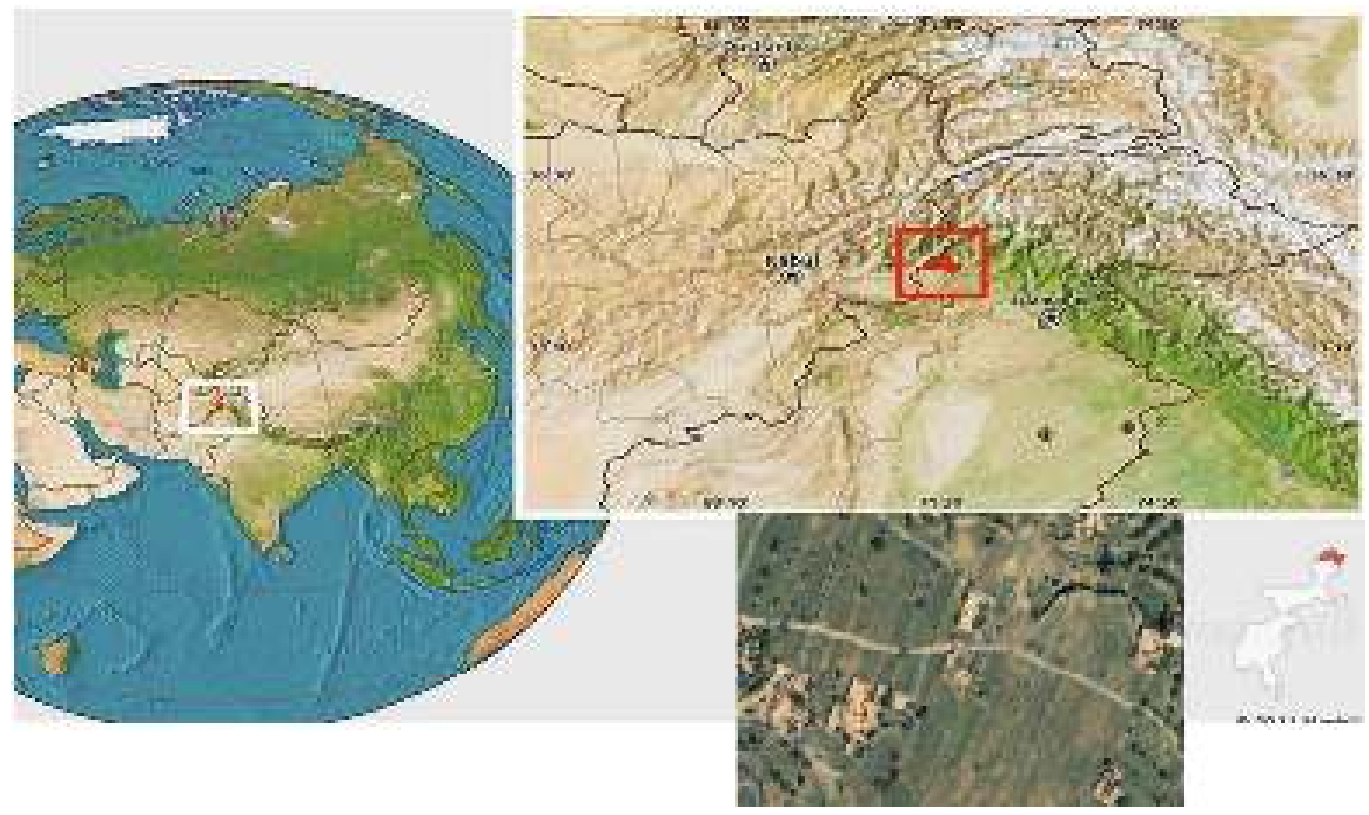

Figure 1. Satellite map of District Bajaur and study area

\section{Design of Experiment}

The experiment was laid out in Randomized Block Design (RBD) with three replications. Each replication consists of 5 treatments. All the treatments were randomized separately in each replication. The plan of layout is displayed in Table 1.

Table 1. Planed layout for experimental design.

\begin{tabular}{|c|c|}
\hline Design & RBD \\
\hline Replication & 5 \\
\hline Treatment & 40 \\
\hline Total Number of Plots & 4 \\
\hline Total Number of Rows Per Plot & $80 \mathrm{~cm}$ \\
\hline Row to Row Distance & $30 \mathrm{~cm}$ \\
\hline Number of Plants Per Row & 20 \\
\hline Plant to Plant Distance & 3 \\
\hline Total Number of Plants Per Plot & Tomato (Lycopersicon esculentum) \\
\hline Number of Plants for Observation Per Plot & Kharif 2019 \\
\hline Crop & Season \\
\hline
\end{tabular}




\section{Collection and Preservation}

Pests affecting the tomato plants were collected according to the procedure described by Gullan and Cranston (2014). Fine hairbrush, forceps and an aspirator were used for pest collection. Pest specimens were preserved in $70 \%$ ethanol.

\section{Method of Treatment}

For the evaluation of insecticidal action experiments were conducted on tomato crops at $20 \mathrm{mg} / \mathrm{ml}$. For this purpose, six rows of tomatoes, $80 \mathrm{~cm}$ apart, were examined. The plot size was restricted to a $10 \times 5 \mathrm{~m}$ area. The populations of Jassids and Whiteflies were recorded by leaving in one row. Moreover, plants were selected randomly. Insects were counted from the upper leaf of the 1st plant, middle leaf of the 2nd plant and lower leaf of the 3rd plant and so on (Razaq et al., 2003). Insecticides were sprayed in recommended dose $(20 \mathrm{mg} / \mathrm{ml})$ when the population of Jassids and Whiteflies reached the economic threshold level (ETL) i.e., 1- 5/ leaf and 4 5/ leaf, respectively (Ahmad, 2000). Insecticides were dissolved in water to prepare working solutions on a vol/vol basis.

\section{Timing of treatment}

The crop was sprayed in the morning before 9 a.m. The population of insect pests was recorded 24, 48 hours after application of insecticides.

\section{Data analysis}

The pest population data were analyzed on the basis of variance by using CoStat v 3.1. (Cohort software, 1993). Significant differences between population means were tested with least significance difference.

\section{RESULTS AND DISCUSSION}

\section{Seasonal Incidence of Major Pests on Tomato in District Bajaur}

In this study, tomato crops were examined from May to September 2019. During the course of the study, the major insect pests recorded were as follows: From 25th May to 17th September, Jassid (Amrasca bigutulla bigutulla Ishida), Aphids (Aphis gossypii Glover), Fruit borer (Helicoverpaarmigera Hub), Whitefly (Bemesia tabaci Genn), and Thrips (Scirtothrips dorsalis Hood). The current study results were supported by many other studies of occurrence of these insects pest on tomato during the study period (Mandal., 2012; Chaudhuri et al.,2001). Tomato is a profitable vegetable due to its availability throughout the year, but pest attack is one of the limiting factors. Our results are in line with another study reported from India which showed the seasonal incidence of Jassid on tomato (Subba et al., 2015). The seasonal incidence of pest (Whitefly, Aphid, fruit borer, thrips) on tomato were also reported that had significant effect on the reduction of production (Rawat, 2019, Hussain and Bilal, 2007, Wade et al., 2020). Aphid damage the sap by using their piercing sucking mouthparts and ultimately lead to decreased leaf surface area. Jassid and whitefly causes leaf curling in tomato leading to heavy production loss. Apart from direct effect Jassid are potential vector of many viruses as well. The honeydew from Jassid on leaf plant attract mold black sooty that can inhibit the photosynthesis and ultimately led to reduction in productivity (subba et al., 2015). Tomato fruit borer is another pest that can attack tomato and causes $40-50 \%$ damage (Pareek and Bhargava 2003). Fruit borer pest larvae infest fruit and make it unsafe for human usage. Thrips damage the tomato plant during feeding. They produce gall structures which are used to identify this type of infestation. Galls are formed in the petioles, sometimes fixing two leaf stalks together, while other species live in every available crevice in the bark. All these pests infestations depend on weather (Mandloi et al., 2015). 


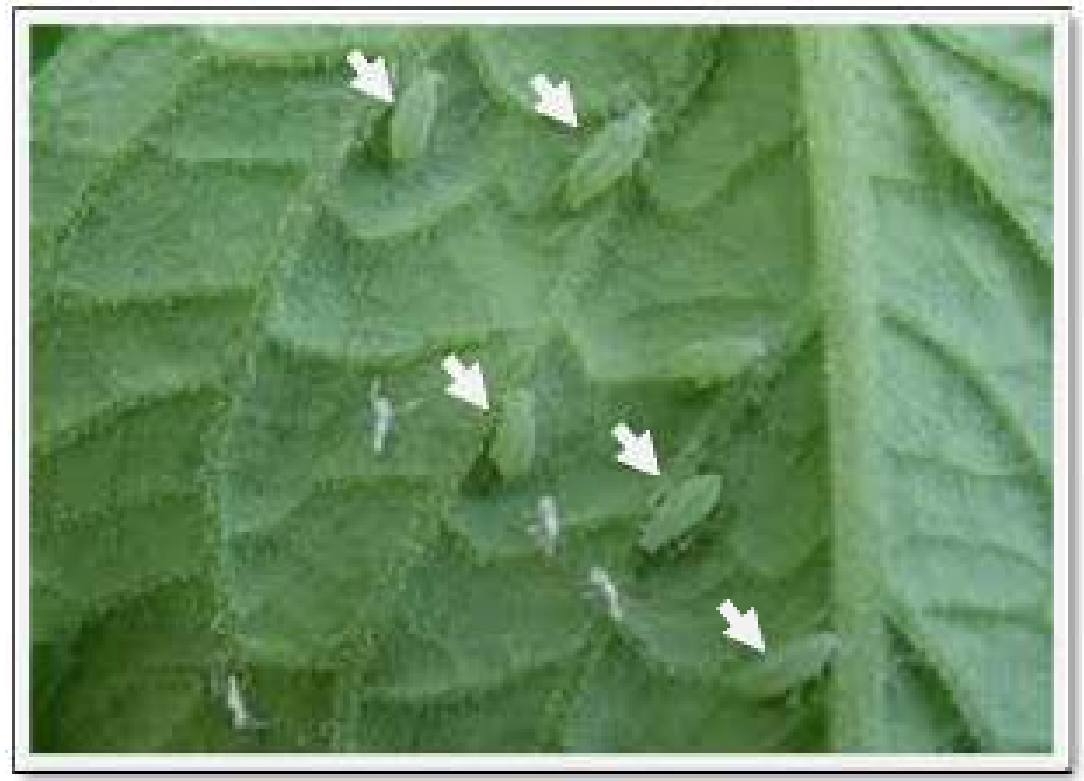

Figure 2. Aphids (Aphis gossypii Glover) present on the leaves shown by white arrows.

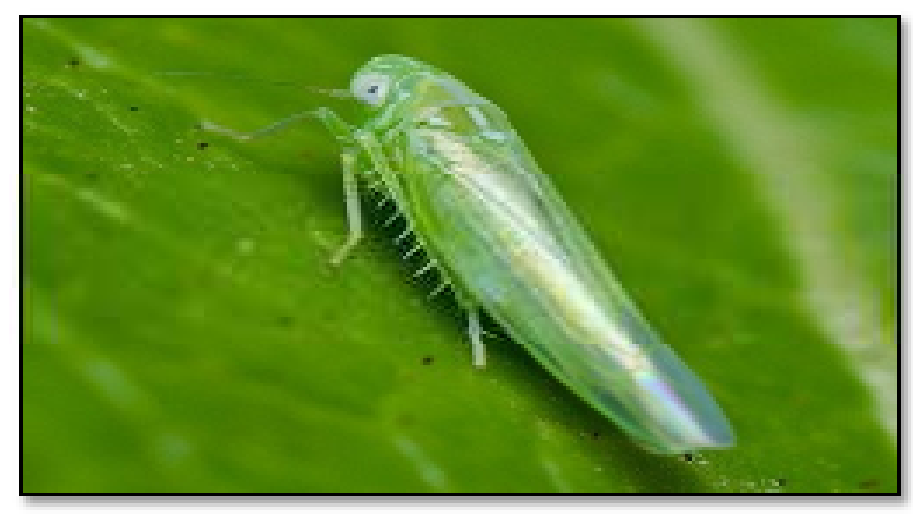

Figure 3.Jassid (amrasca biguttulabiguttula) present on the leaves.

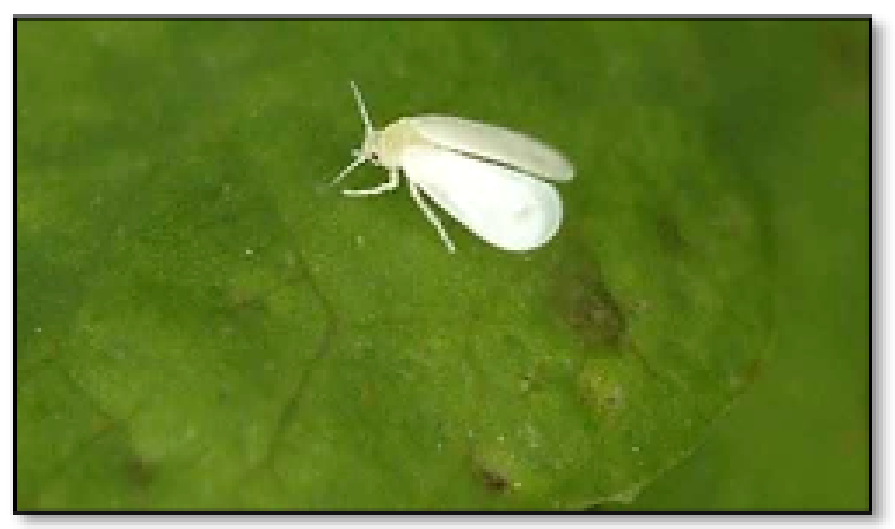

Figure 4. Whitefly (Bemisia tabaci Genn) present on the leaves 


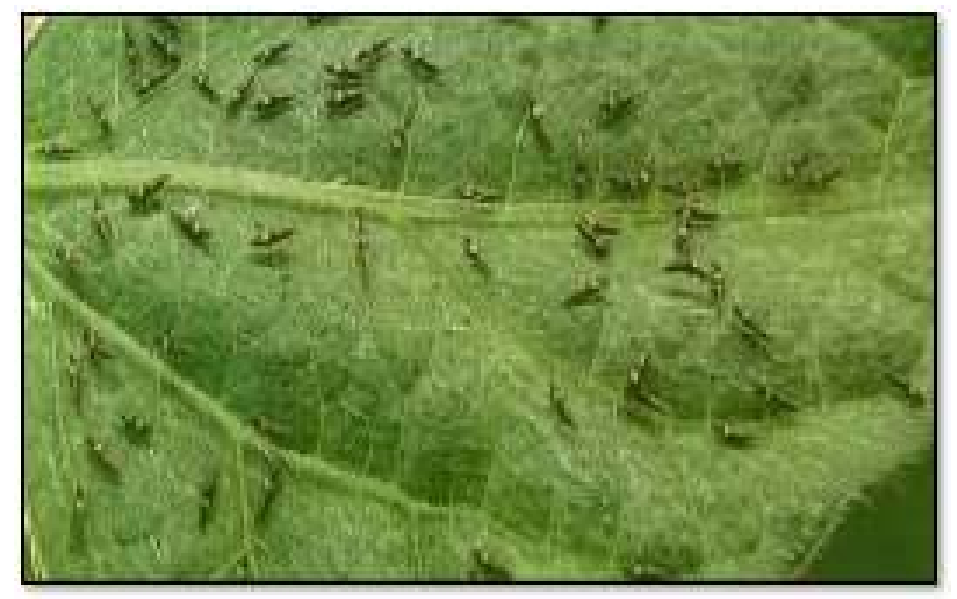

Figure 5.Thrips (Scirtothrips dorsalis Hood) present on the leaves of tomato.

\section{Management of Pests by using pesticide}

The Efficacy of pesticide against major insect pests of tomato were evaluated. Flurofenafire was applied to examine the incidence of Aphis gosypii, AmrascaBiguttulaBiguttula, Helicoverpa armigera Hub, Bemisia tabaci Genn infestations of the tomato plant. The tomato crop was observed before spraying and after spraying to check the treatment effects. Pesticides had a broad range of effects, on one side it provides its importance for management of pests and pathogens and on another side, it also had influence on other non-targets organisms (asad et al., 2017, Xu et al., 2010, Zhang et al., 2009, Zhang et al., 2016, Bull et al., 2006).

\section{Pesticide Flurofenafire effect on Aphids (Aphis gossypii Glover)}

The insecticidal effects of Flurofenafire were evaluated on pest "Aphids" that attack tomato plant. The pre-treatment population of aphids was observed uniformly in different months of tomato crop cultivation with the peak population of aphids being recorded in May $(1.21 \%)$ and in July $(19.90 \%)$ (Table 2 ). The average minimum population was observed in the early stage of tomato cultivation, while their maximum population was observed during the month of August (Table 2). In treatment group the population of Aphids were decreased relative to untreated group. The population of Aphis gosypii decrease with time; on the seventh day after spraying all the treatments had significantly lower populations of pests than the untreated control (Table 3). The highest mortality of Aphids was observed in the month of September (figure 6). Another study reported the similar observation by studying the population dynamics of aphid (Sunil, 2017). Studies discussing correlation between aphids and environmental parameters showed positive relation (Sunil, 2017). Our study also showed relationship between aphids and environmental conditions; in warmer environment higher aphids population was observed (July) whereas reduction in population with lower temperature. So, it is concluded that under warm condition Aphids can cause more damage and rainfall can reduced the damage to tomato plants (Sunil, 2017).

\section{Pesticide Flurofenafire effect on Jassids bigutullabigutulla Ishida)}

In pre-treatment group population of Jassids was observed from May to September. The highest population was recorded in May and in September without use of any pesticides (Table 2). The population of Amrasca Biguttula Biguttula decrease over time following the application of pesticides (Table 2). Table 2 and 3 show the average population of pests in untreated and treated plots of the tomato crops respectively. The average 
minimum population was observed in the early stage of tomato cultivation, while their maximum population was observed during the month of September (Table 2). The reduction in Jassids population were observed within 24 hours of post insecticide treatment (Table 3). Highest mortality was observed in the month of September, proved that the treatment was effective after 24 and 48 hours. Table 4 and 5 showed the Mean, Standard Deviation, and variance of the untreated plots, which were $49.20,29.765$ and 885.956 respectively, while the values for the treated plots were, $18.80,17.631$ and 310.844 respectively. Fig. 7 gave a comparative account of the rise and fall of the pests in non-treated and treated plots. Our results are supported by another study using an environmentally friendly pesticide to manage Jassids and whitefly (Ramesh and Ukey, 2006). They showed similar initial effects of insecticide on Jassids as our study.

\section{Pesticide Flurofenafire effect on Thrips (Scirtothrips dorsalis Hood).}

The effect of Flurofenafire on trips was also investigated to gain insight into its mortality. In the pretreatment group higher population of thrips were recorded relative to treated group (Table 2,3 ). The treatments were found to be significantly more effective than the untreated control. The average minimum population was observed in the early stage of tomato cultivation, while their maximum population was observed during the month of August (Table 2). Minimum Thrip populations were observed after 24 hours in plots treated with insecticide during 2019 (Table 3). Highest mortality was observed in the month of September (figure 8). In other study chlorfenapyr was shown to be effective against $S$. dorsalis and significantly reduced their densities upon treatments (Seal et al., 2006).

\section{Pesticide Flurofenafire effect on Whitefly (Bemisia tabaci Genn)}

The pre-treatment population of white fly was observed in different months.
The population was found to peak from $0.99 \%$ in May up to $20.89 \%$ in August. The population of white fly were significantly reduced than untreated control after spraying. The lowest population was found in the early stages of tomato cultivation ( 24 hours) after pesticide treatment (Table 3). A peak population was observed during August (Table 2). The average minimum population was observed in the early stage of tomato, while their maximum population was observed during the month of August (Table 2). Minimum whiteflies were observed in plots treated with insecticide, 24 hours after application of insecticides during 2019 (Table 3). Highest mortality was observed in the month of September, proved to be effective 24 and 48 hours after application of insecticides. Mortality in treated plots was not much higher than plots not receiving insecticide during crop season of 2019. This might be due to killing of natural enemies or resistance. Table 4 and 5 showed their Mean, Standard Deviation and variance of the untreated plots were found to be 20.10, 14.035 and 196.989 and treated plots were, $10.30,9.178$ and 84.233 respectively. Fig. 9 gave a comparative account of the rise and fall of the pests in non-treated and treated plots. The tomato plant in initial 50-60 days is under higher susceptibility for numerous gemini viruses, thus treatment during this period emphasize to reduced vector and host plant connection (Jahel et al., 2017). Our study also reported the appearance of whitefly in the initial days of seedling. The virus free seedling production for thirty days is a comprehensive opportunity for integrated management of whitefly-gemini viruses complex. This is possible under tunnels covered by fine nets. Other pre-preparatory plan will further improve the management such as covering grounds and on time insecticide application. 
Fruit borer is another insect that hampered the productivity and production of tomato. This insect attack on developing fruits and reduced the yield by $20-60 \%$ (Ravi et al., 2008, Talekar et al., 2006). In current study area fruit borer was seen to attack on tomato plant from May to September. The average minimum population was observed in the early stage of tomato cultivation, while their maximum population was observed during the month of September in untreated group (Table 2). Upon treatment with Flurofenafire significant effects was observed on the reduction of fruit borer (Table 3 ). Highest mortality was observed in the month of September, indicating that the treatment was most effective 24 and 48 hours after application. Table 4 and 5 showed the Mean, Standard Deviation, and variance values of the untreated plots, which were $35.50 \%, 26.551 \%$ and $704.944 \%$ respectively, while the values for the treated plots were, $13.90 \%, 10.577 \%$ and $111.878 \%$ respectively. Fig 10 give a comparative account of the rise and fall of the pests fruit borer in non-treated and treated plots. Our results are accordance to the findings of (Thilagam, 2003) which showed the effects on fruit borer in tomato crop. Other insecticide reported in literature had also shown significant effect on the fruit borer larval stage such as Deltamethrin and fluvalinate (Hussain and Bilal, 2007) 
Table 2:Shows average no. of insect pests in untreated tomato plant in Bajaur from May to September with Average temperature and Humidity.

\begin{tabular}{|c|c|c|c|c|c|c|c|c|}
\hline Month & \begin{tabular}{|l|} 
Avg \\
Temp
\end{tabular} & RH\% & $\begin{array}{l}\text { Rain } \\
\text { (Days) }\end{array}$ & Aphids & Jassid & Thrips & White fly & $\begin{array}{l}\text { Fruit } \\
\text { borer }\end{array}$ \\
\hline \multirow[t]{3}{*}{ May } & 34 & 74 & - & 5 & 7 & 4 & 3 & 3 \\
\hline & 35 & 72 & - & 13 & 11 & 5 & 3 & 3 \\
\hline & 38 & 69 & - & 18 & 9 & 6 & 2 & 4 \\
\hline \multirow[t]{3}{*}{ June } & 40 & 20 & - & 24 & 18 & 5 & 6 & 12 \\
\hline & 40 & 21 & - & 30 & 27 & 7 & 7 & 15 \\
\hline & 41 & 24 & - & 36 & 40 & 5 & 11 & 18 \\
\hline \multirow[t]{3}{*}{ July } & 40 & 22 & - & 32 & 44 & 8 & 23 & 29 \\
\hline & 41 & 21 & - & 50 & 65 & 10 & 24 & 34 \\
\hline & 42 & 81 & 2 & 82 & 81 & 13 & 28 & 40 \\
\hline \multirow[t]{3}{*}{\begin{tabular}{|l|} 
August \\
\end{tabular}} & 35 & 90 & 4 & 46 & 67 & 18 & 35 & 48 \\
\hline & 36 & 87 & - & 51 & 60 & 12 & 36 & 36 \\
\hline & 30 & 77 & 3 & 74 & 72 & 17 & 42 & 56 \\
\hline \multirow[t]{3}{*}{ September } & 26 & 88 & 5 & 60 & 84 & 3 & 30 & 67 \\
\hline & 27 & 81 & - & 45 & 71 & 7 & 26 & 66 \\
\hline & 23 & 86 & 2 & 29 & 70 & 4 & 21 & 78 \\
\hline
\end{tabular}


Table 3:Shows average no. of insect pests in treated tomato plant in Bajaur from May to September with Average temperature and Humidity

\begin{tabular}{|c|c|c|c|c|c|c|c|c|}
\hline Month & $\begin{array}{l}\text { Avg } \\
\text { Temp }\end{array}$ & RH\% & $\begin{array}{c}\text { Rain } \\
\text { (Days) }\end{array}$ & Aphids & Jassids & Thrips & $\begin{array}{c}\text { White } \\
\text { fly }\end{array}$ & $\begin{array}{l}\text { Fruit } \\
\text { borer }\end{array}$ \\
\hline \multirow[t]{3}{*}{ May } & 34 & 74 & - & 1 & 2 & 2 & 2 & 2 \\
\hline & 35 & 72 & - & 3 & 2 & 1 & 2 & 1 \\
\hline & 38 & 69 & - & 4 & 4 & 2 & 1 & 1 \\
\hline \multirow[t]{3}{*}{ June } & 40 & 20 & - & 10 & 5 & 2 & 3 & 4 \\
\hline & 40 & 21 & - & 6 & 8 & 1 & 5 & 3 \\
\hline & 41 & 24 & - & 9 & 12 & 1 & 4 & 4 \\
\hline \multirow[t]{3}{*}{ July } & 40 & 22 & - & 16 & 18 & 7 & 18 & 16 \\
\hline & 41 & 21 & - & 32 & 26 & 2 & 17 & 17 \\
\hline & 42 & 81 & 2 & 40 & 39 & 5 & 16 & 28 \\
\hline \multirow[t]{3}{*}{ August } & 35 & 90 & 4 & 21 & 23 & 6 & 20 & 18 \\
\hline & 36 & 87 & & 51 & 30 & 3 & 24 & 22 \\
\hline & 30 & 77 & 3 & 61 & 57 & 6 & 27 & 29 \\
\hline \multirow[t]{3}{*}{ September } & 26 & 88 & 5 & 21 & 22 & 1 & 8 & 21 \\
\hline & 27 & 81 & & 9 & 10 & 1 & 6 & 14 \\
\hline & 23 & 86 & 2 & 4 & 6 & 1 & 4 & 16 \\
\hline
\end{tabular}

Table 4: Mean, Range and standard deviation for pest in untreated plants.

\begin{tabular}{|l|l|l|l|l|l|l|l|l|}
\hline Pest & No & Range & $\begin{array}{l}\text { Minim } \\
\text { um }\end{array}$ & $\begin{array}{l}\text { Maxim } \\
\text { um }\end{array}$ & \multicolumn{2}{l|}{ Mean } & Sd & $\begin{array}{l}\text { Varian } \\
\text { ce }\end{array}$ \\
\cline { 2 - 9 } & $\begin{array}{l}\text { Statis } \\
\text { tic }\end{array}$ & $\begin{array}{l}\text { Statisti } \\
\text { c }\end{array}$ & $\begin{array}{l}\text { Statist } \\
\text { ic }\end{array}$ & $\begin{array}{l}\text { Statisti } \\
\text { c }\end{array}$ & $\begin{array}{l}\text { Statis } \\
\text { tic }\end{array}$ & $\begin{array}{l}\text { St. } \\
\text { Error }\end{array}$ & $\begin{array}{l}\text { Statisti } \\
\text { c }\end{array}$ & $\begin{array}{l}\text { Statist } \\
\text { ic }\end{array}$ \\
\hline Aphids & 10 & 77 & 5 & 82 & $\begin{array}{l}41.2 \\
0\end{array}$ & $\begin{array}{l}8.01 \\
6\end{array}$ & $\begin{array}{l}25.35 \\
0\end{array}$ & $\begin{array}{l}642.6 \\
22\end{array}$ \\
\hline Jassids & 10 & 77 & 7 & 84 & $\begin{array}{l}49.2 \\
0\end{array}$ & $\begin{array}{l}9.41 \\
3\end{array}$ & $\begin{array}{l}29.76 \\
5\end{array}$ & $\begin{array}{l}885.9 \\
56\end{array}$ \\
\hline Thrips & 10 & 15 & 3 & 18 & 8.30 & $\begin{array}{l}1.77 \\
7\end{array}$ & 5.618 & 31.567 \\
\hline White fly & 10 & 40 & 2 & 42 & $\begin{array}{l}20.1 \\
0\end{array}$ & $\begin{array}{l}4.43 \\
8\end{array}$ & $\begin{array}{l}14.03 \\
5\end{array}$ & $\begin{array}{l}196.9 \\
89\end{array}$ \\
\hline $\begin{array}{l}\text { Fruitbore } \\
\text { r }\end{array}$ & 10 & 75 & 3 & 78 & $\begin{array}{l}35.5 \\
0\end{array}$ & $\begin{array}{l}8.39 \\
6\end{array}$ & $\begin{array}{l}26.55 \\
1\end{array}$ & $\begin{array}{l}704.9 \\
44\end{array}$ \\
\hline
\end{tabular}


Table 5: Mean, Range and standard deviation for pest in treated plants.

\begin{tabular}{|l|l|l|l|l|l|l|l|l|}
\hline Pest & No & Range & $\begin{array}{l}\text { Minim } \\
\text { um }\end{array}$ & $\begin{array}{l}\text { Maxim } \\
\text { um }\end{array}$ & \multicolumn{2}{l|}{ Mean } & Sd & $\begin{array}{l}\text { Varia } \\
\text { nce }\end{array}$ \\
\cline { 2 - 9 } & $\begin{array}{l}\text { Statisti } \\
\text { c }\end{array}$ & $\begin{array}{l}\text { Statisti } \\
\text { c }\end{array}$ & $\begin{array}{l}\text { Statisti } \\
\text { c }\end{array}$ & $\begin{array}{l}\text { Statisti } \\
\text { c }\end{array}$ & $\begin{array}{l}\text { Statisti } \\
\text { c }\end{array}$ & $\begin{array}{l}\text { St.Erro } \\
\text { r }\end{array}$ & $\begin{array}{l}\text { Statist } \\
\text { ic }\end{array}$ & $\begin{array}{l}\text { Statisti } \\
\text { c }\end{array}$ \\
\hline Aphids & 10 & 60 & 1 & 61 & 18.70 & 5.941 & $\begin{array}{l}18.78 \\
6\end{array}$ & $\begin{array}{l}352.90 \\
0\end{array}$ \\
\hline Jassids & 10 & 55 & 2 & 57 & 18.80 & 5.575 & $\begin{array}{l}17.63 \\
1\end{array}$ & $\begin{array}{l}310.84 \\
4\end{array}$ \\
\hline Thrips & 10 & 6 & 1 & 7 & 3.30 & .761 & 2.406 & 5.789 \\
\hline White fly & 10 & 26 & 1 & 27 & 10.30 & 2.902 & 9.178 & 84.233 \\
\hline $\begin{array}{l}\text { Fruit } \\
\text { borer }\end{array}$ & 10 & 28 & 1 & 29 & 13.90 & 3.345 & $\begin{array}{l}10.57 \\
7\end{array}$ & $\begin{array}{l}111.87 \\
8\end{array}$ \\
\hline
\end{tabular}

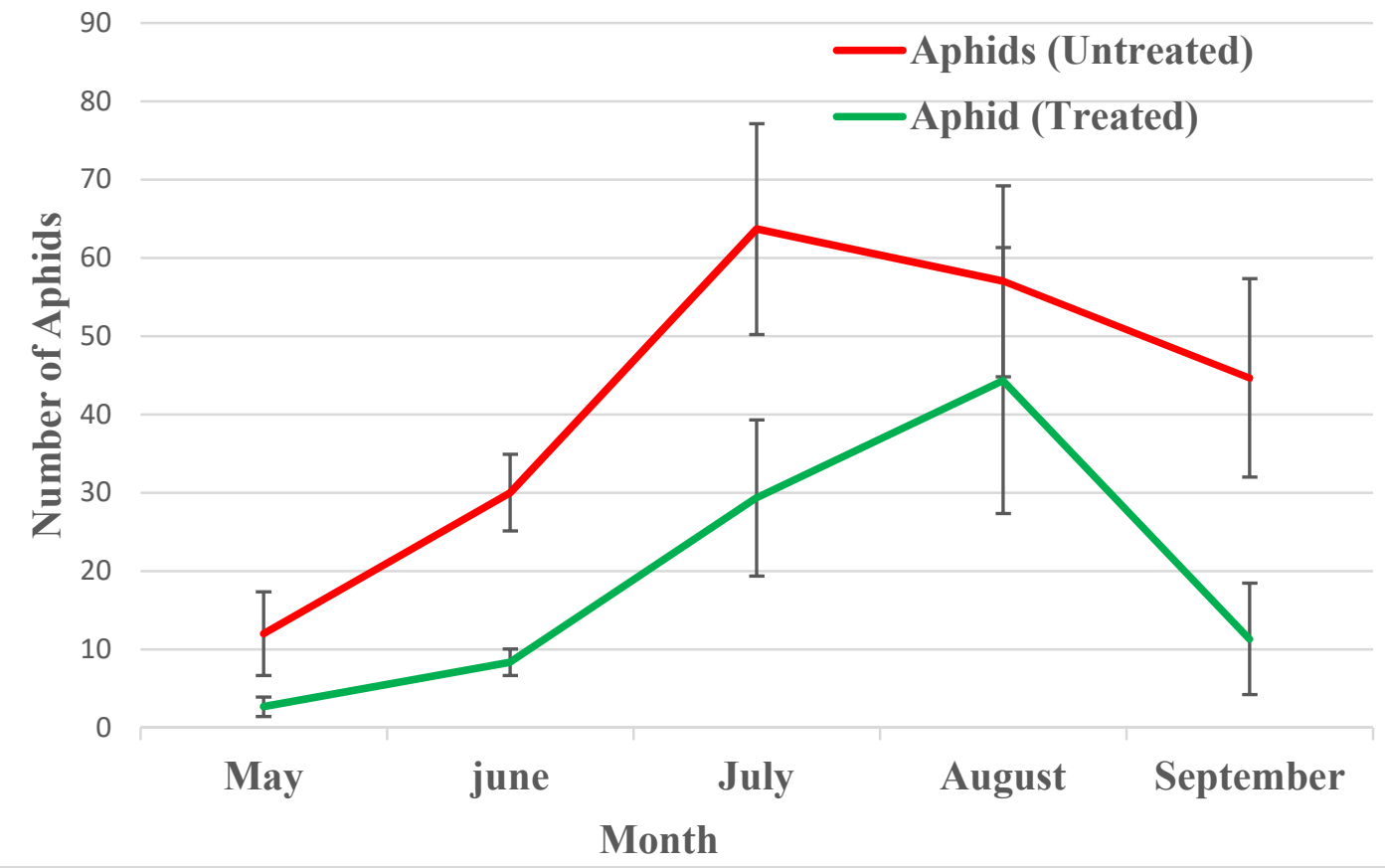

Figure 6. Distribution of Aphid in untreated and treated tomato plant in Bajaur from May to September. The results were quantified from three individual experiments. 


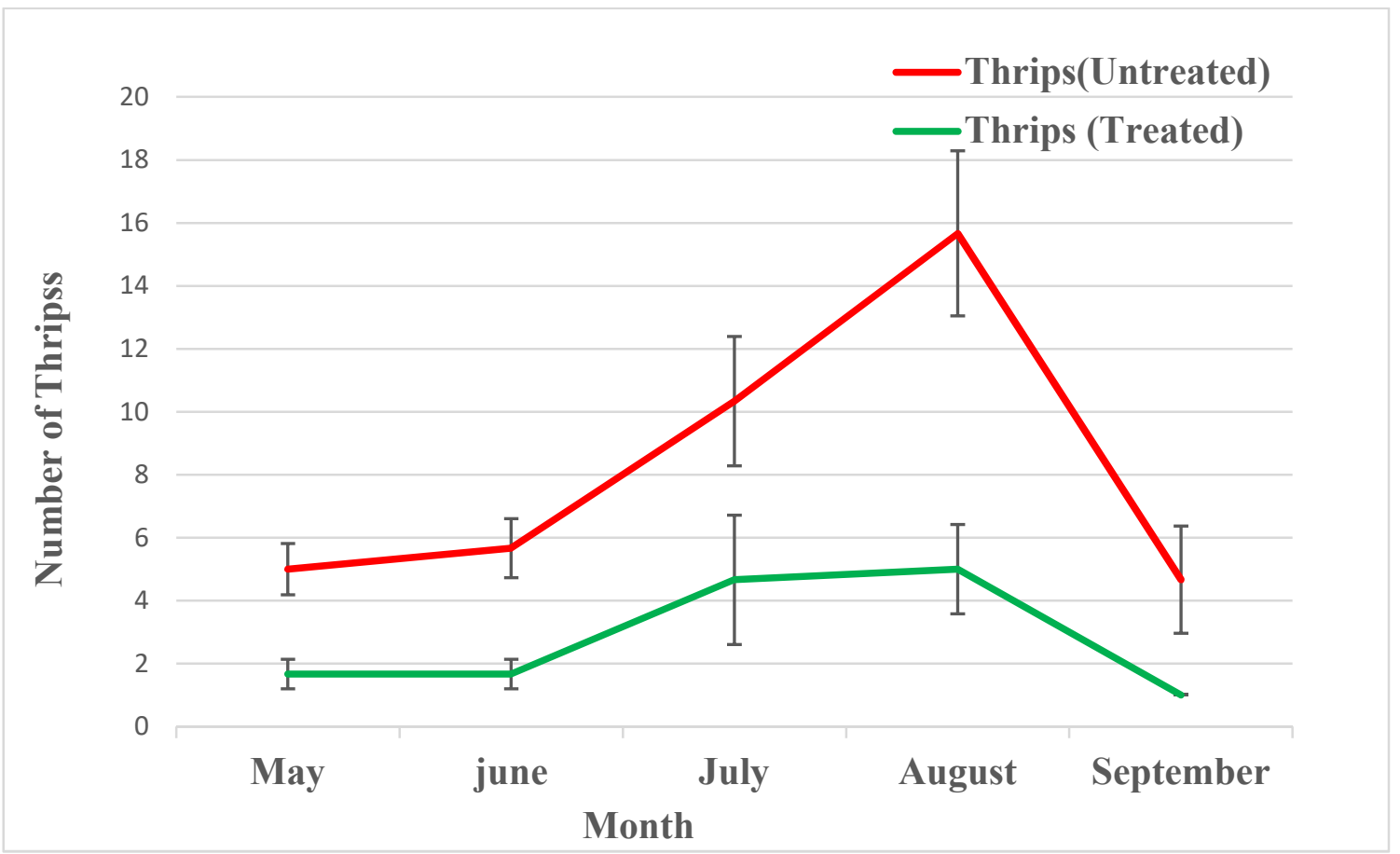

Figure 7.Distribution of Thrip in untreated and treated tomato plant in Bajaur from May to September. The results were quantified from three individual experiments.

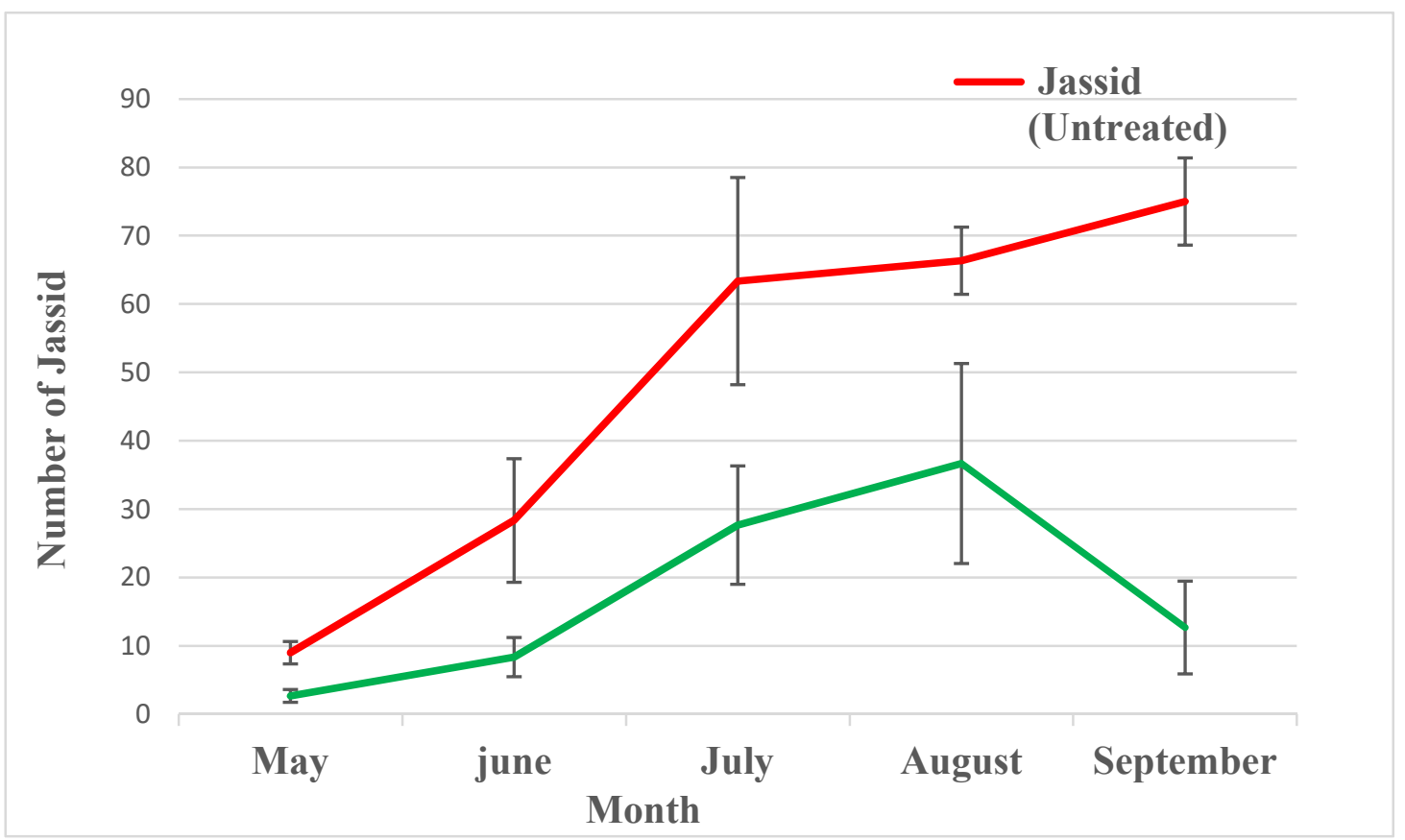

Figure 8. Distribution of Jassids in untreated and treated tomato plant in Bajaur from May to September. The results were quantified from three individual experiments. 


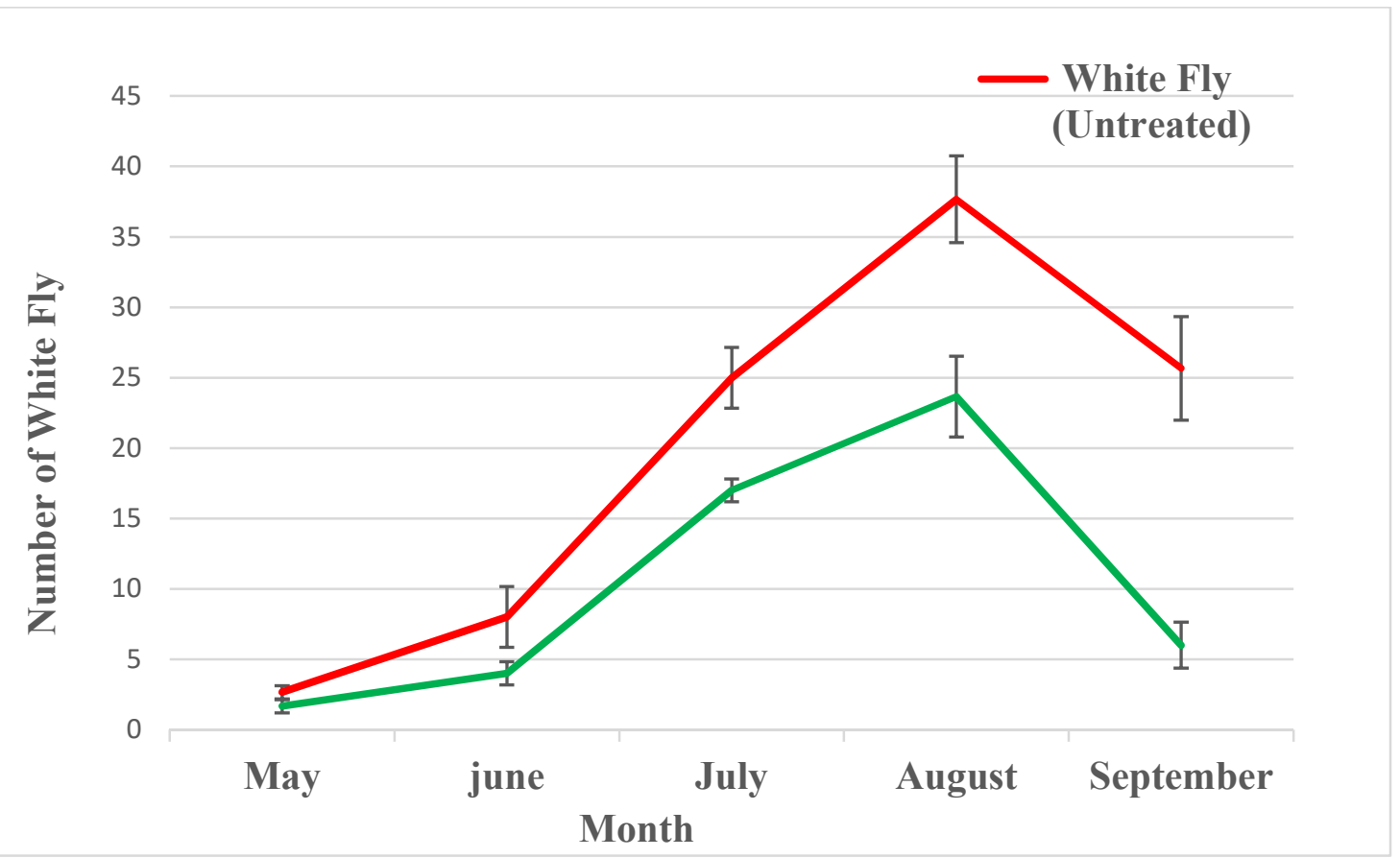

Figure 9.Distribution of White Fly in untreated and treated tomato plant in Bajaur from May to September. The results were quantified from three individual experiments.

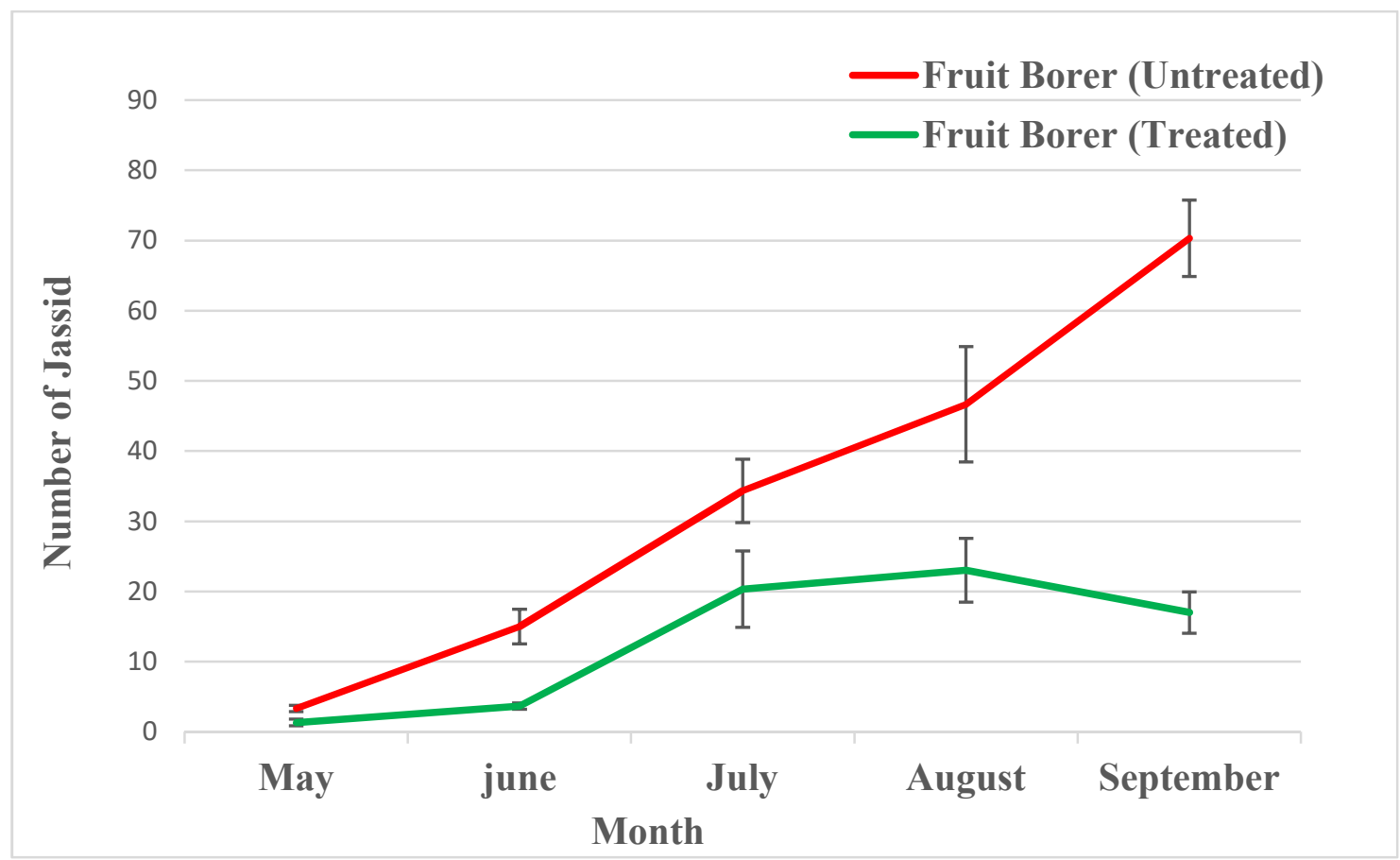

Figure 10.Distribution of Fruit Bore in untreated and treated tomatoplant in Bajaur from May to September. The results were quantified from three individual experiments. 


\section{CONCLUSION}

It is concluded from the current study that tomato plant is attack by the rich fauna of insect in Bajaur, Pakistan. The different types of tomato pests such as Aphis gosypii, Amrasca bigutulla bigutulla, Bemisia tabaci Genn, Scirtothrips dorsalis and Helicoverpa armigera can be controlled by the use of pesticide, Flurofenafire. Thus, the yield of the tomato plant can be increased by the use of pesticides and traditional cultivation methods.

\section{ACKNOWLEDGMENT}

We, the authors are extremely thankful and acknowledge the support of local farmers of district Bajaur for providing consent to monitor and treat their plant with insecticide. The authors are thankful for the financial assistance and research facility provided by the department of Botany University of Malakand KP Pakistan. 


\section{REFERENCES CITED}

Afreen, S., T.N. Shamsi, M.A. Baig, N. Ahmad, S. Fatima, M.I. Qureshi, M.I Hassan and T. Fatma. 2017. A novel multicopper oxidase (laccase) from cyanobacteria: purification, characterization with potential in the decolorization of anthraquinonic dye. PloS. One. 12(4): 0175144.

Akhtar, K.P., M.Y. Saleem, M. Asghar, M. Ahmad and N. Sarwar.2010. Resistance of Solanum species to Cucumber mosaic virus subgroup IA and its vector Myzuspersicae. Eur. J. Plan Path. 128(4): 435-450.

Asad, M., M. Lavoie, H. Song, Y. Jin, Z. Fu and $\mathrm{H}$. Qian. 2017. Interaction of chiral herbicides with soil microorganisms, algae and vascular plants. Sci. Total Environ. 580: 12871299.

Bull, S., K. Fletcher, A.R. Boobis and J.M. Battershill. 2006. Evidence for genotoxicity of pesticides in pesticide applicators: A review. Mutagenesis. 21: 93-103.

Gu, L., Z. Bai, B. Jin, Q. Hu, H. Wang, G. Zhuang and $H$. Zhang. 2010. Assessing the impact of fungicide enostroburin application on bacterial community in wheat phyllosphere. J. Environ. Sci. 22: 134-141.

Gullan, P.J. and P.S. Cranston, P. S. 2014. The insects: an outline of entomology. John Wiley \& Sons.

Hussain, B. and S. Bilal. 2007. Efficacy of different insecticides on tomato fruit borer Helicoverpaarmigera. $J$. Entomol. 4(1): 64-67.

Ijaz, A., I. Khan, S. Zareen, M.I. Khan, R. Khan, and M. Haroon.2017. Yield and Yield Attributes of Tomato (Lycopersiconesculentum Mill) Cultivars Influenced by Weed Management Techniques. Pak. J. Weed Sci. Res. 23(4).1-8.

Jahel, M.K., S.M. Halawa, A.A. Hafez, T.R. Abd El-Zahar and K. Elgizawy.2017. Comparative efficacy of different insecticides against whitefly, Bemisiatabaci (Gennadius)
(Homoptera: Aleyrodidae) on Tomato Plants. Middle. East. J. App. Sci. 7(4): 786-793.

Khalid, U., A. Ejaz, M.U. Khan, A. Atiq, I. Adeel, I. Javed. 2005. Integrated weed management in okra. Pak. J. Weed Sci. Res. 11(1/2): 55-60.

Kil, E.J., S. Kim, Y.J. Lee, H.S. Byun, J. Park, H. Seo, S. Lee. 2016. Tomato yellow leaf curl virus (TYLCV-IL): a seed-transmissible geminivirus in tomatoes. Sci. Rep. 6(1): 1-10.

Luckmann, W.H. and R.L. Metcalf. 1975. Introduction to insect pest management. 1-60.

Mandloi, R., R. Pachori, A.K. Sharma, M. Thomas, and A.S. Thakur. 2015. Impact of weather factors on the incidence of major insect pests of tomato (solanum lycopersicon I.) cV. $\mathrm{H}-86$ (Kashi Vishesh). The Ecoscan, 7-12.

Pareek, P.L. and M.C. Bhargava. 2003. Estimation of avoidable losses in vegetables caused by borers under semi-arid condition of Rajasthan. Insect Environ. 9(2): 59-60.

Ramesh, R. and S.P. Ukey. 2006. Bio-efficacy of eco-friendly insecticides against tomato jassids and whitefly. J. Plant Prot. Enviro. 3(1): 122-126.

Ravi, M., G. Santharam, and N. Sathiah. 2008. Ecofriendly management of tomato fruit borer, Helicoverpaarmigera (Hubner). J. Biopestic. 1(2): 134-137.

Rawat, N. 2019.Seasonal Incidence of Whitefly and Aphid on Tomato Crop at Tarai Region of Uttrakhand. Int. j. pure appl. biosci. 7(5): 214-221.

Razaq, S., R.J. Wilkins, and J.P. Urban.2003. The effect of extracellular $\mathrm{pH}$ on matrix turnover by cells of the bovine nucleus pulposus. Eur. Spine J. 12(4): 341-349. 
Riley, W.T., D.E. Rivera, A.A. Atienza, W. Nilsen, S.M. Allison, and R. Mermelstein. 2011. Health behavior models in the age of mobile interventions: are our theories up to the task? Transl. Behav. Med. 1(1): 53-71.

Said, F., M. Inayatullah, S. Ahmad, I. Khan, Saeed-ul-Haq and M. Zaman. 2015. Comparing the effect of different plant extracts with a chemical insecticide for management of the aphid, Aphis gossypii in sunflower. Pak. J. Weed. Sci.Res.21(3): 359-368.

Seal, D.R., M. Ciomperlik, M.L. Richards, and W. Klassen. 2006. Comparative effectiveness of chemical insecticides against the chillithrips, Scirtothrips dorsalis Hood (Thysanoptera: Thripidae), on pepper and their compatibility with natural enemies. Crop. Protec. 25(9): 949-955.

Subba, B., S.K. Ghosh, K.R. Kumar, M.R. Bhanusree, and B. Chetri. 2015. Seasonal incidence of jassid infesting tomato (Lycopersiconesculentum (L.) and their sustainable management. In Compendium of abstracts of the 2nd international conference on bio-resource and stress management, ANGRAU \& PJTSAU, Hyderabad.7-10.

Sunil, K.R. 2017.Seasonal Incidence of aphid (Aphis gossypii Glove.) Infesting tomato (Lycopersiconesculentum L.) and their management by using botanical pesticides.Int. j. adv. eng. Tech. 3(1): 1-4.

Talekar, N.S., R.T. Opena, and P. Hanson. 2006. Helicoverpa armigera management: a review of AVRDC's research on host plant resistance in tomato. Crop Protection. 25(5): 461-467.

Thilagam, P. 2003. Evaluation of Bacillus thuringiensis var. kurstaki Berliner (Spic Bio) against pod borer complex of pigeon pea and tomato fruit borer. Unpublished M. Sc. (Ag)
Thesis, Tamil Nadu Agricultural University, Coimbatore, India, 126.

Wade, P.S., S.M. Wankhede, N.K. Hatwar, B.D. Shinde, P.B. Sanap. 2020. Seasonal incidence of major pests infesting tomato (Solanum lycopersicum L.). J. Entomol. Zool.8(3): 1546-1548.

WPTC. 2018. WPTC 2018 global estimate currently stands at 37.1 million metric tonnes. Available online at [http://www.tomatonews.com/en/wp tc-2018-global-estimate-currently-st ands-at-371-million-metric-tonnes_2 _284.html].

Zhang, B., Z. Bai, D. Hoefel, L. Tang, X. Wang, B. Li, Z. Li and G. Zhuang. 2009. The impacts of cypermethrin pesticide application on the non-target microbial community of the pepper plant phyllosphere. Sci. Total Environ. 407: 1915-1922.

Zhang, M., Z. Xu, Y. Teng, P. Christie, J. Wang, W. Ren, Y. Luo and Z. Li. 2016. Non-target effects of repeated chlorothalonil application on soil nitrogen cycling: The key functional gene study. Sci. Total Environ. 543: 636-643. 